\title{
RECOVERY OF METALS FROM ELECTROACTIVE COMPONENTS OF SPENT Ni-MH BATTERIES AFTER LEACHING WITH FORMIC ACID
}

\author{
Pedro Rosário Gismonti, Jéssica Frontino Paulino and Júlio Carlos Afonso *
}

Department of Analytical Chemstry, Institute of Chemstry, Federal University of Rio de Janeiro, Cidade Universitária, Ilha do Fundão, 21941-909, Brazil

Article Info:
Received:
17 August 2020
Revised:
1 February 2021
Accepted:
16 February 2021
Available online:
31 March 2021
Keywords:
Spent Ni-MH batteries
Formic acid
Solvent extraction
Oxalates
Sodium formate

Article Info

17 August 2020

Revised:

Accepted:

16 February 2021

31 March 2021

Keywords:

Spent Ni-MH batteries

Solvent extraction

Sodium formate

\begin{abstract}
This work describes a route for recovering nickel, cobalt, iron, zinc, and lanthanides from spent nickel-metal hydride batteries. Formic acid was used as leachant. Experiments were run at $25-50^{\circ} \mathrm{C}$ for $1-4 \mathrm{~h}$. Under the best conditions leaching yields surpassed $99 \mathrm{wt} . \%$, except for iron. The insoluble matter contains almost solely iron as iron(III) basic formate. The leachate went through six separation procedures, combining solvent extraction with D2EHPA as extractant, and precipitation reactions. $\mathrm{Fe}^{2+}$ and $\mathrm{Zn}^{2+}$ were extracted together (>99 wt.\%) from the original leachate ( $\mathrm{pH}$ 1.5). Yttrium and lanthanides were precipitated as oxalates directly from the raffinate (> 99.9 wt.\%) upon addition of sodium oxalate. In the next steps, $\mathrm{Mn}^{2+}$ and $\mathrm{Co}^{2+}$ were extracted with D2EHPA at buffered $\mathrm{pH}$ (3 and $\sim 4.8$, respectively), after adding $\mathrm{NaOH}_{\text {aq }}$. About 10 wt.\% of leached $\mathrm{Ni}^{2+}$ was coextracted with $\mathrm{Co}^{2+}$. The remaining $\mathrm{Ni}^{2+}$ was precipitated from the raffinate after addition of aqueous sodium oxalate at $\mathrm{pH} 6$. After precipitation of $\mathrm{Al}^{3+}$ upon addition of $\mathrm{NaOH}_{\text {aq }}$. until $\mathrm{pH} \sim 8$, sodium formate was recovered after slow evaporation of the final aqueous solution at $60^{\circ} \mathrm{C}$. It contains $\sim 90 \mathrm{wt} . \%$ of the formate present in the leachant.
\end{abstract}

\section{INTRODUCTION}

Rechargeable nickel-metal hydride (Ni-MH) batteries are widely used as a power source for small devices such as mobile phones, digital cameras, toys (Fila et al., 2019) and are also found in hybrid electric vehicles (HEV) (Meshram et al., 2017; Korkmaz et al., 2018). Ni-MH batteries have replaced common AA and AAA sizes $\mathrm{Zn}-\mathrm{C}$ (alkaline and Leclanché) batteries in Brazil (Fernandes et al., 2012, 2013) and nickel-cadmium ( $\mathrm{Ni}-\mathrm{Cd}$ ) cells.

The cathode is a porous polymer impregnated with a "paste" containing active nickel compounds and $\mathrm{Ni}(\mathrm{II})$ hydroxide. The anode is also composed of a porous polymer impregnated with a mixture of metals including rare earth elements (REEs) and others such as $\mathrm{Fe}, \mathrm{Co}, \mathrm{Ni}, \mathrm{Cu}$, $\mathrm{Zn}, \mathrm{Al}$, capable of hydride formation. The active anode is hydrogen ions which during charging and discharging of the battery are absorbed and desorbed by the above mentioned metals. The electrodes are separated by a synthetic porous membrane which enables the contact of electrolyte ( $\mathrm{KOH}$ solution) contained in electrode space with both electrodes (Fila et al., 2019). The electrode charging and discharging processes are described in the literature (Lucas et al., 2015).
$\mathrm{Ni}-\mathrm{MH}$ batteries contain base and valuable metals such as REEs, nickel and cobalt in considerable amounts (Oliveira et al., 2017; Meshram et al., 2016). Consumption of REEs, a group of 17 elements including the lanthanides (La-Lu), Sc and $Y$, has increased significantly in recent years due to their application in high technology areas, including magnets (computers, wind turbines etc.), phosphor powders (fluorescent lamps/tubes), $\mathrm{Ni}-\mathrm{MH}$ batteries, catalysts, special glasses and metal alloys. Resources of REEs are neither abundant nor evenly distributed across the world (Meshram et al., 2016). REEs have been declared as high supply risk materials by the European Commission (Korkmaz et al., 2018).

The cost and environmental problems associated with the disposal of wastes and scraps in landfills have emerged as the major concern for most nations (Musariri et al., 2019), and also means a waste of non-renewable resources (Gao et al., 2018; Shih et al., 2019; Fu et al., 2019). Recycling of such wastes and scraps may significantly reduce the dependence on primary resources of many elements. Spent $\mathrm{Ni}-\mathrm{MH}$ batteries are one of such wastes which may be turned to a potential secondary resource (Meshram et al., 2019).

Several hydrometallurgical processes have been 
worked out on different scales to recover metals from spent $\mathrm{Ni}-\mathrm{MH}$ batteries. Sulfuric and hydrochloric acids have been widely used as leachants (Fernandes et al., 2013; Santos et al., 2014; Turek, 2018; Korkmaz et al., 2018; Oliveira et al., 2017), in the concentration range from 1 to $12 \mathrm{~mol} \mathrm{~L}^{-1}$, at a temperature range from 25 to $95^{\circ} \mathrm{C}$, over a long period of time (> $80 \mathrm{~min}$ ) (Turek, 2018). The addition of a reductant like hydrogen peroxide improves leaching of many metals as it converts sparingly soluble forms in higher oxidation states (e.g., $\mathrm{Co}^{3+}, \mathrm{Ni}^{3+}, \mathrm{Mn}^{4+}$ ) to lower valence ions (e.g., $\mathrm{Co}^{2+}, \mathrm{Ni}^{2+}, \mathrm{Mn}^{2+}$ ) which are leachable and stable in acidic solution (Vieceli et al., 2018; Santos et al., 2014).

Disposal of acidic leachates is one of the main problems leading to economic and energy losses (Wang et al., 2020; Chen et al., 2018). An opportunity to reduce the environmental impact of hydrometallurgical processes lies in the use of organic acids as leachants. They are biodegradable, delay corrosion of equipments, are safer to handle and emit less toxic gases than strong acids (Gao et al., 2018; Meshram et al., 2020). Studies involving organic acids (citric, oxalic, acetic) only focused the leaching step (Alonso et al., 2017; Colmenares et al., 2018). Separation and purification steps are required for recovery of metal ions from their leachates. It may be difficult to extract many elements due to the strong chelation of some metal ions with carboxylic anions (Fu et al., 2019).

Leached elements are usually separated one from each other by a combination of separation techniques. REEs may either be recovered by solvent extraction (Xie et al., 2014; Paulino et al, 2018) or precipitated as oxalates (Fernandes et al., 2013; Josso et al., 2018; Yang et al., 2014; Oliveira et al., 2017). The use of aqueous two-phase systems (ATPSs) and ion-exchange resins have been also tested for REE recovery (Valadares et al., 2018; Fila et al., 2019). Multiple stages are generally required to separate $\mathrm{Co}(\mathrm{II})$ from $\mathrm{Ni}(\mathrm{II})$, which have similar chemical properties (Gaines, 2018; Dhiman and Gupta, 2019).

Like oxalic acid, formic acid, the simplest aliphatic monocarboxylic acid, is a strong reductant, but does not precipitate metal ions as does oxalate (Lurie, 1978; Feigl, 1958). It is a versatile renewable reagent for green and sustainable chemical synthesis and processes. It is safer to handle than concentrated inorganic acids (Vieceli et al., 2018; Liu et al., 2015). It is a promising candidate as a leachant for spent batteries (Fu et al., 2019, Ibiapina et al., 2018, Silva et al., 2018), particularly Li-ion ones. Apparently, less attention has been paid to processing of spent $\mathrm{Ni}-\mathrm{MH}$ batteries in the presence of organic acids. Therefore, the objective of the present investigation is to develop a hydrometallurgical process to recover base metals and REEs from the electroactive components of spent $\mathrm{Ni}-\mathrm{MH}$ batteries in the presence of formic acid as leachant, while optimizing various parameters such as acid concentration, leaching time and temperature. The novelty elicited in this research is to determine the effectiveness of this acid as a leachant for spent $\mathrm{Ni}-\mathrm{MH}$ batteries in the place of strong inorganic acids and the feasibility of leachate processing by current separation techniques.

\section{MATERIALS AND METHODS}

\subsection{Samples}

120 spent AA Ni-MH batteries (the most common rechargeable size in Brazil) were collected from the local market. To prevent short-circuiting and self-ignition during dismantling, samples were completely discharged first. After manual dismantling, the electroactive components (cathode, anode, electrolyte) were separated. This mass was dried at $105^{\circ} \mathrm{C}$ for $3 \mathrm{~h}$ before being ground using a ball mill and sieved through a $100 \mu \mathrm{m}$ sieve. In previous work by this research group, elemental analysis was performed by X-ray fluorescence (Fernandes et al., 2013) using the same equipment and procedure described in Section 2.7. Data are presented in Table 1. Water is basically the volatile component lost during drying.

\subsection{Reagents}

Di-2-ethylhexylphosphoric acid (D2EHPA, 98 wt.\%) was supplied by Sigma-Aldrich. n-Hexane (Sigma-Aldrich) was used as diluent. Formic acid (Sigma-Aldrich, 88 wt.\%, 20 mol L-1), sulfuric acid (Merck, $98 \mathrm{wt} . \%, \sim 18 \mathrm{~mol} \mathrm{~L}^{-1}$ ), sodium hydroxide $\left(6 \mathrm{~mol} \mathrm{~L}^{-1}\right)$ and sodium oxalate (Merck) were of analytical grade. The solutions were prepared with distilled water.

\subsection{Leaching}

Baaed on leching studies involving electroative components of spent batteries (Meshram et al., 2019, 2020; Fernandes et al., 2013; Chen et al., 2018; Yang et al., 2014), the following variables were studied: temperature $\left(25-50^{\circ} \mathrm{C}\right)$, formic acid concentration (5-15 $\mathrm{mol} \mathrm{L}^{-1}$ ) and time (1-4 h). The sample mass to acidic leachant volume ratio was fixed at $100 \mathrm{~g} \mathrm{~L}^{-1}$.

Experiments were performed in $150 \mathrm{~mL}$ glass beakers equipped with a magnetic stirrer. The leaching temperature

TABLE 1: Chemical analyses data of the electroactive components of spent Ni-MH batteries after drying at $105^{\circ} \mathrm{C}$ for $3 \mathrm{~h}$ (Fernandes et al., 2013).

\begin{tabular}{c|cc}
\hline Element & Amount (wt.\%) & $\begin{array}{c}\text { Relative standard } \\
\text { deviation (\%) }\end{array}$ \\
\hline La & $8.9 \pm 0.3$ & 3.4 \\
\hline Pr-Sm & $2.3 \pm 0.4$ & 17.4 \\
\hline Y & $0.7 \pm 0.1$ & 14.3 \\
\hline Mn & $0.3 \pm 0.1$ & 33.3 \\
\hline Fe & $1.3 \pm 0.1$ & 7.7 \\
\hline Co & $2.7 \pm 0.1$ & 3.7 \\
\hline $\mathrm{Ni}$ & $3.2 \pm 0.6$ & 18.8 \\
\hline $\mathrm{Zn}$ & $27.2 \pm 1.1$ & 4.0 \\
\hline $\mathrm{Na}$ & $0.7 \pm 0.1$ & 14.3 \\
\hline $\mathrm{K}$ & $3.7 \pm 0.6$ & 16.2 \\
\hline $\mathrm{Ca}$ & $10.4 \pm 0.2$ & 1.9 \\
\hline $\mathrm{Al}$ & $0.6 \pm 0.2$ & 28.6 \\
\hline Loss of volatiles & $37.6 \pm 1.4$ & 33.3 \\
\hline & & 3.7 \\
\hline
\end{tabular}


was controlled by water bath. The aqueous formic acid was added to the beaker and heated to the required temperature at 200 rotations per minute. The instance when the solid was added to the acidic solution was considered as the start of the experiment.

At the end of the experiment the leachate was filtered (under vacuum) through a quantitative filter paper, yielding a green filtrate and a brown residue. This residue was washed with water $\left(3 \mathrm{~mL} \mathrm{~g}^{-1}\right.$ processed solid), dried at $110^{\circ} \mathrm{C}$ for $3 \mathrm{~h}$ and weighed. It was then placed in a ceramic crucible and calcined in a furnace $\left(1000^{\circ} \mathrm{C}, 3 \mathrm{~h}\right)$. The roasted mass was cooled down in the furnace and weighed.

All experiments were performed to verify the reproducibility of them. It was found that the error percentage was on the order of $\pm 3 \%$.

The separation procedure employed was based on precipitation and solvent extraction techniques conducted under increasing $\mathrm{pH}$ and evaporation of the final solution to recover the formate ion. Figure 1 presents the general scheme for elements separation from the leachates.

Electroactive components

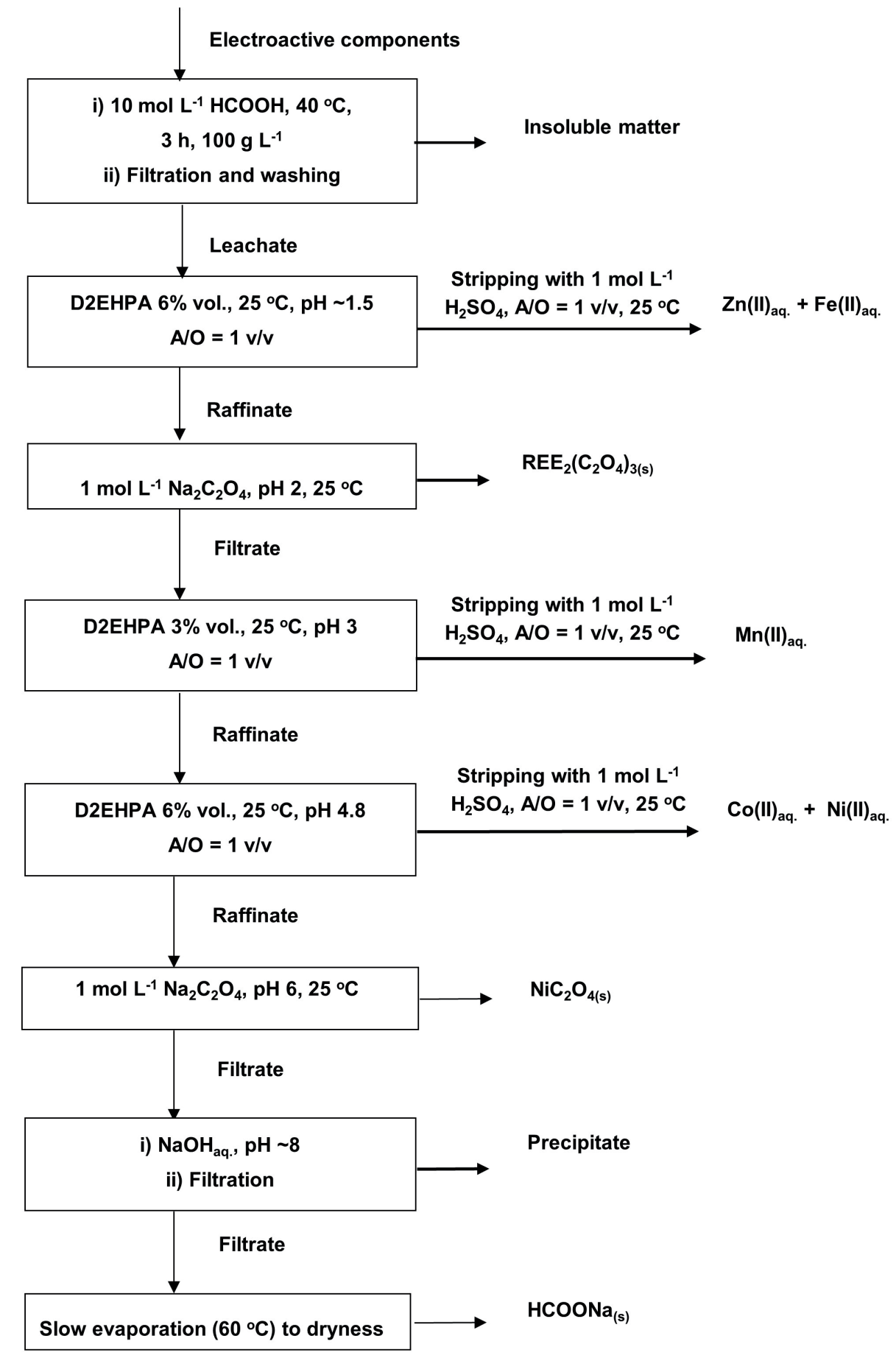

FIGURE 1: General scheme for elements separation from leachates from electroactive components of spent Ni-MH batteries after leaching with $\mathrm{HCOOH}$. 


\subsection{Solvent extraction of $\mathrm{Zn}(\mathrm{II}), \mathrm{Fe}(\mathrm{II}), \mathrm{Mn}$ (II) and $\mathrm{Co}$ (II) and stripping procedures}

Precipitation using hydroxide, sulphide and carbonate does not perform well in a system containing $\mathrm{Co}$ (II) and $\mathrm{Mn}(\mathrm{II})$ due to their similar chemical properties (Barik et al., 2017). D2EHPA, a cation exchanger, is frequently used as extractant in both research and industrial applications (Virolainen et al., 2011). Extraction experiments were performed in glass separatory funnels at $25^{\circ} \mathrm{C}$. Extractant concentration varied from 1 to $10 \mathrm{vol} . \%$. The aqueous/organic (A/O) phase ratio was fixed at 1 vol./vol. $\mathrm{pH}$ of the leachate was adjusted by adding the appropriate amount of $6 \mathrm{~mol}$ $\mathrm{L}^{-1} \mathrm{NaOH}$. The system was shaken for $5 \mathrm{~min}$. Phase separation was achieved in $\sim 10 \mathrm{~min}$. The experiments were carried out in triplicate and the experimental error including the analytical error was $4 \%$ at a confidence level of $95 \%$. The amount of element extracted was calculated by the difference between the concentration in the raffinate and the concentration in the original leachate.

Stripping was carried out at $25^{\circ} \mathrm{C}$ using aqueous sulfuric acid in glass separatory funnels. Its concentration varied from 0.05 to $5.0 \mathrm{~mol} \mathrm{~L}^{-1}$. The aqueous/organic (A/O) phase ratio was fixed at $1 \mathrm{vol} / \mathrm{vol}$. The system was shaken for $10 \mathrm{~min}$. Phase separation was achieved in $\sim 5 \mathrm{~min}$. The experiments were carried out in triplicate and the experimental error including the analytical error was $3 \%$ at a confidence level of $95 \%$.

\subsection{Precipitation of REEs and $\mathrm{Ni}(\mathrm{II})$}

Given the high amounts of REEs in the material under study, the method chosen to recover them was the precipitation of their oxalates (Josso et al., 2018; Chiu et al., 2019) at low $\mathrm{pH}(<2)$.

The experiments were accomplished in glass beakers. After solvent extraction of $\mathrm{Zn}(\mathrm{II})$ and $\mathrm{Fe}(\mathrm{II})$, the raffinate was stirred (200 rotations per minute) at $25^{\circ} \mathrm{C} .6 \mathrm{~mol} \mathrm{~L}^{-1}$ $\mathrm{NaOH}$ was added dropwise (about $1 \mathrm{~mL} \mathrm{~min}^{-1}$ ) in order to adjust $\mathrm{pH}$ at $\sim 2.1 \mathrm{~mol} \mathrm{~L}^{-1} \mathrm{Na}_{2} \mathrm{C}_{2} \mathrm{O}_{4}$ was added dropwise until ceased precipitation of a white solid $\left(\mathrm{X}_{2}\left(\mathrm{C}_{2} \mathrm{O}_{4}\right)_{3}, \mathrm{X}=\mathrm{Y}, \mathrm{La}\right.$, $\mathrm{Ce}, \mathrm{Pr}, \mathrm{Nd}, \mathrm{Sm})$. It was filtered through a quantitative paper, washed with $0.01 \mathrm{~mol} \mathrm{~L}^{-1} \mathrm{Na}_{2} \mathrm{C}_{2} \mathrm{O}_{4}$ and water, dried at $110^{\circ} \mathrm{C}$ for $3 \mathrm{~h}$ and weighed.

After solvent extraction of $\mathrm{Co}(\mathrm{II}), \mathrm{pH}$ of the raffinate was adjusted at $\sim 6$ by adding $6 \mathrm{~mol} \mathrm{~L}^{-1} \mathrm{NaOH} .1 \mathrm{~mol} \mathrm{~L}^{-1} \mathrm{Na}-$ ${ }_{2} \mathrm{C}_{2} \mathrm{O}_{4}$ was added dropwise at $25^{\circ} \mathrm{C}$ and $200 \mathrm{rpm}$. A green precipitate $\left(\mathrm{NiC}_{2} \mathrm{O}_{4}\right)$ was formed. It was filtered through a quantitative paper and washed with $0.01 \mathrm{~mol} \mathrm{~L}^{-1} \mathrm{Na}_{2} \mathrm{C}_{2} \mathrm{O}_{4}$ and water. The filtrate was colorless.

\subsection{Crystallization of sodium formate}

$\mathrm{pH}$ of the raffinate was adjusted to $\sim 8$ by adding $6 \mathrm{~mol}$ $\mathrm{L}^{-1} \mathrm{NaOH}$ at $25^{\circ} \mathrm{C}$ and $200 \mathrm{rpm}$. A gelatinous precipitate was formed at $\mathrm{pH} \sim 6$ (Hayrapetyan et al., 2006) and separated by filtration under vacuum.

The filtrate was slowly evaporated at $60^{\circ} \mathrm{C}$ (without stirring) in a glass vessel. A white crystalline solid was obtained. It was dried at $110^{\circ} \mathrm{C}$ for $2 \mathrm{~h}$, ground with an agate mortar and pestle, weighed and kept in a tightly closed container.

\subsection{Analytical methods}

Metal ion concentrations in the aqueous solutions were determined by atomic absorption spectrometry (AAS) on a Varian/Agilent SpectrAA 50b spectrometer. $\mathrm{pH}$ measurements were performed using a combination of a glass electrode and an $\mathrm{Ag} / \mathrm{AgCl}$ reference electrode (Orion $2 \mathrm{Al}^{3-J G}$ ). The solids obtained during processing of the leachates were weighed in an analytical balance (Scientech SA 120) and analyzed by X-ray fluorescence (Shimadzu XRF 800 HS). Crystalline phases in the solid samples were identified by X-ray diffraction (Shimadzu XRD 6000) by continuous scanning method at $20 \mathrm{~mA}$ and $40 \mathrm{kV}$, using $\mathrm{Cu}$ $\mathrm{Ka}(1.5418 \AA)$ as the radiation source. Data were collected in the two-theta range of $10^{\circ}-70^{\circ}\left(5^{\circ} \mathrm{min}^{-1}\right)$.

Classical qualitative tests for $\mathrm{Fe}(\mathrm{III}), \mathrm{Fe}(\mathrm{II}), \mathrm{Mn}(\mathrm{II})$, $\mathrm{Co}(\mathrm{II}), \mathrm{Zn}(\mathrm{II})$ and $\mathrm{Ni}(\mathrm{II})$ were also applied to monitor the presence of such species in the leachates or solids (Vogel, 1981; Feigl, 1958; Lurie, 1978). Detection limits are in the order of $0.1-1.0 \mathrm{mg} \mathrm{L}^{-1}$.

\section{RESULTS AND DISCUSSION}

\subsection{Leaching}

\subsubsection{Effects of temperature and time}

The effects of reaction temperature and time on leaching were investigated using $10 \mathrm{~mol} \mathrm{~L}^{-1}$ formic acid. The results are shown in Figure 2 and 3 for nickel, lanthanium and iron, the most abundant metals in the electroactive components (Table 1). An increase in the temperature greatly improved leaching of nickel and lanthanium, attaining $\sim 100 \mathrm{wt} \%$ at $40^{\circ} \mathrm{C}$ after $3 \mathrm{~h}$. A similar effect was observed in some studies involving leaching of $\mathrm{Zn}-\mathrm{C}$ and Li-ion batteries in the presence of organic acids (Ibiapina et al., 2018; Silva et al., 2018; Musariri et al., 2019). The other REEs behaved as lanthanium. Iron leaching was much less relevant, not surpassing 20 wt.\%. Formic acid served the dual role of leachant and reductant for nickel, thus making addition of a reductant like hydrogen peroxide unnecessary.

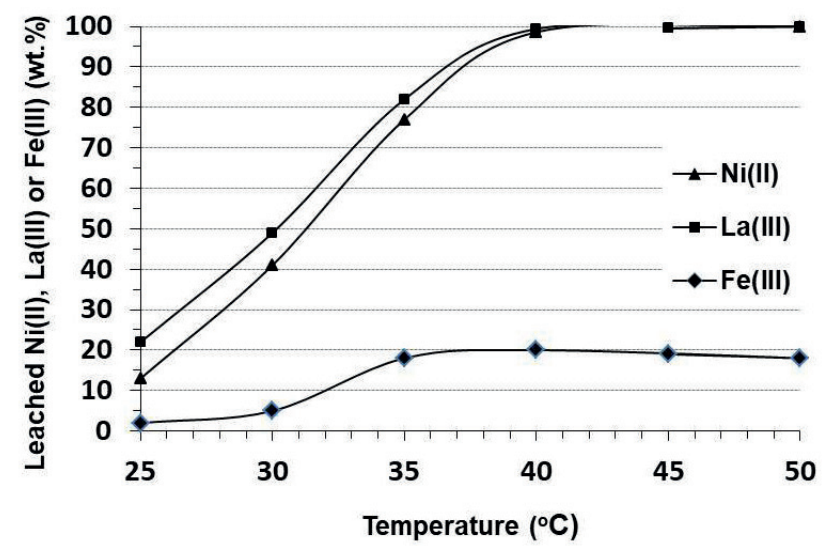

FIGURE 2: Effect of temperature on leaching $\left(10 \mathrm{~mol} \mathrm{~L}-1{ }^{-1} \mathrm{HCOOH}\right.$, $\left.3 \mathrm{~h}, \mathrm{~S} / \mathrm{L}=100 \mathrm{~g} \mathrm{~L}^{-1}\right)$. 


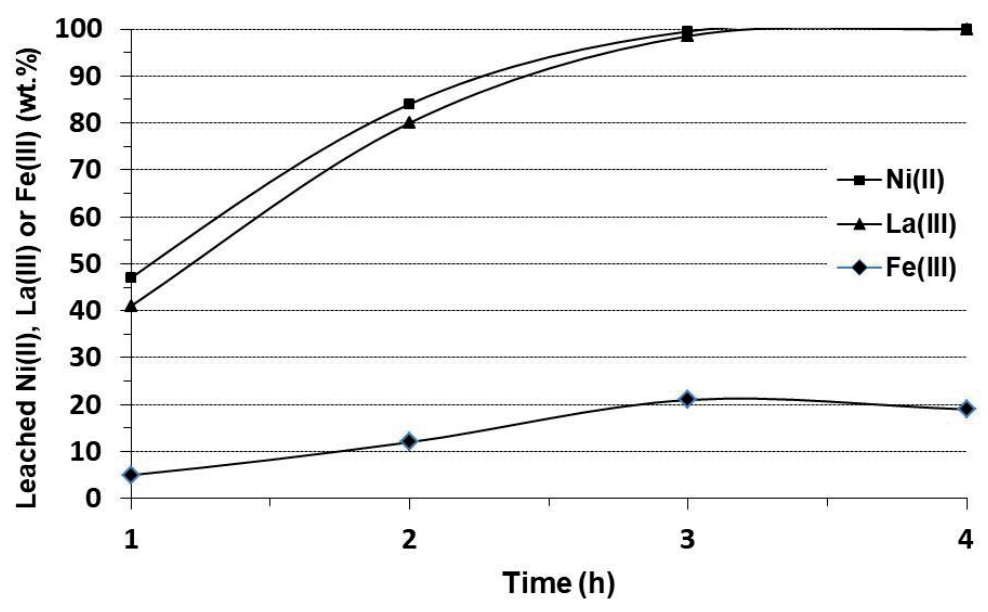

FIGURE 3: Effect of time on leaching $\left(10 \mathrm{~mol} \mathrm{~L}^{-1} \mathrm{HCOOH}, 40^{\circ} \mathrm{C}, \mathrm{S} / \mathrm{L}=100 \mathrm{~g} \mathrm{~L}^{-1}\right)$.

\subsubsection{Effect of acid concentration}

Figure 4 shows the effect of formic acid concentration on metals leaching under the following conditions: $\mathrm{S} / \mathrm{L}$ ratio, $100 \mathrm{~g} \mathrm{~L}^{-1}$; leaching time, $3 \mathrm{~h}$; temperature, $40^{\circ} \mathrm{C}$. When the acid concentration increased from 5 to $10 \mathrm{~mol}$ $\mathrm{L}^{-1}$, leaching increased from below $40 \%$ to almost $100 \mathrm{wt}$. $\%$. Thereafter, acid concentrations did not significantly affect the leaching performance. Once again, iron leaching was low in all experiments.

The optimum experimental conditions found for formic acid in the present study are comparable to those normally reported for inorganic acids (Turek, 2018) and for leaching of Li-ion batteries in the presence of organic acids (Fu et al., 2019), except the S/L ratio. In general, literature reports a S/L ratio in the range $2-50 \mathrm{~g} \mathrm{~L}^{-1}$ (Alonso et al., 2017; Colmenares et al., 2018; Fu et al., 2019; Fernandes et al., 2013; Santos et al., 2014; Korkmaz et al., 2018; Oliveira et al., 2017), but the concentration of the organic acid is much lower $\left(<5 \mathrm{~mol} \mathrm{~L}^{-1}\right)$ than in the present study.

\subsection{Leachates composition}

Table 2 presents the average concentration of elements after leaching under the best experimental conditions (10 $\mathrm{mol} \mathrm{L}-1 \mathrm{HCOOH}, 40^{\circ} \mathrm{C}, 3 \mathrm{~h}$ ). Based on the chemical analysis presented in Table 1, more than 99 wt.\% of all metals present in the electroactive materials were leached under mild conditions with respect to temperature, except iron, where only 20 wt.\% were leached.

\subsection{Analysis of the insoluble matter}

Under the best conditions $\left(10 \mathrm{~mol} \mathrm{~L}^{-1} \mathrm{HCOOH}, 40^{\circ} \mathrm{C}, 3\right.$ h) the brown insoluble matter after leaching corresponds only to $2.2 \mathrm{wt}$.\% of the initial mass. XRF data (Table 3 ) show that iron is by far the most abundant element, together with minute quantities of nickel and lanthanium. This result agrees with the low iron leaching by formic acid (Table 2). The diffractogram of the insoluble matter is presented in Figure 5. No crystalline phases were identified.

Based on the amount of insoluble matter recovered

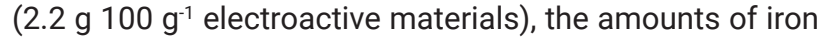

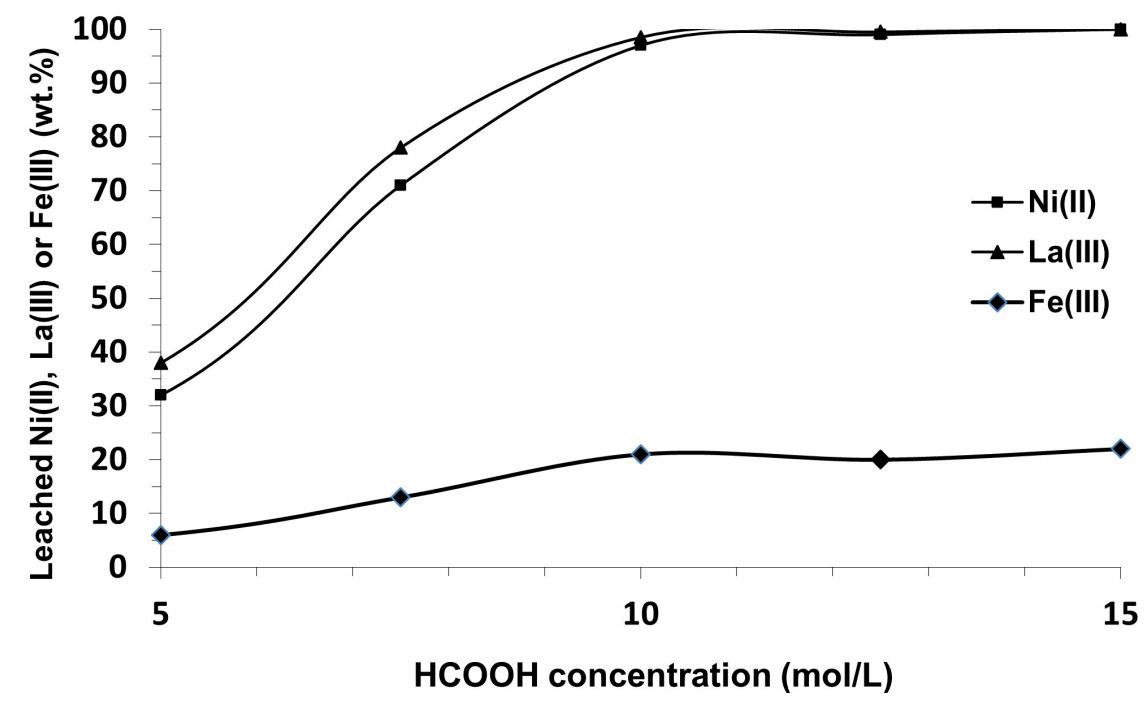

FIGURE 4: Effect of formic acid concentration on leaching $\left(40{ }^{\circ} \mathrm{C}, 3 \mathrm{~h}, \mathrm{~S} / \mathrm{L}=100 \mathrm{~g} \mathrm{~L}^{-1}\right)$. 
TABLE 2: Element concentrations in the leachates.

\begin{tabular}{|c|c|c|}
\hline Element & $\begin{array}{c}\text { Concentration } \\
\qquad\left(\mathrm{g} \mathrm{L}^{-1}\right)\end{array}$ & $\begin{array}{l}\text { Relative standard } \\
\text { deviation (RSD, \%) }\end{array}$ \\
\hline $\mathrm{Ni}$ & $27.7 \pm 0.5$ & 1.8 \\
\hline $\mathrm{La}$ & $8.9 \pm 0.4$ & 4.5 \\
\hline Co & $3.1 \pm 0.3$ & 9.7 \\
\hline $\mathrm{Ce}$ & $2.3 \pm 0.2$ & 8.7 \\
\hline $\mathrm{Mn}$ & $1.3 \pm 0.1$ & 7.7 \\
\hline Pr-Sm & $0.7 \pm 0.1$ & 14.3 \\
\hline $\mathrm{Zn}$ & $0.7 \pm 0.1$ & 14.3 \\
\hline $\mathrm{Ca}$ & $0.5 \pm 0.1$ & 20.0 \\
\hline $\mathrm{Fe}$ & $0.5 \pm 0.1$ & 20.0 \\
\hline $\mathrm{Al}$ & $0.3 \pm 0.0$ & 0.0 \\
\hline $\mathrm{Y}$ & $0.2 \pm 0.0$ & 0.0 \\
\hline $\mathrm{Ca}$ & $0.6 \pm 0.2$ & 28.6 \\
\hline $\mathrm{Al}$ & $0.3 \pm 0.1$ & 33.3 \\
\hline Loss of volatiles & $37.6 \pm 1.4$ & 3.7 \\
\hline
\end{tabular}

in both solids (Tables 1 and 3) and the leached iron (Table 2 ), one may conclude that $80 \mathrm{wt}$.\% of iron is present in the insoluble matter. This solid was easily dissolved in $1 \mathrm{~mol} \mathrm{~L}^{-1}$ $\mathrm{H}_{2} \mathrm{SO}_{4}$ at $25^{\circ} \mathrm{C}$. Only $\mathrm{Fe}(\mathrm{III})$ was found in the brown-orange solution formed (Vogel, 1981; Feigl, 1958), the test with thiocyanate in $\mathrm{HCl}$ medium was positive.

The ash recovered after calcination of the insoluble matter corresponds to $43 \mathrm{wt}$.\% of the initial mass. It is very likely that the brown solid is iron(III) basic formate (Vogel, 1981):

$6 \mathrm{HCOO}-+3 \mathrm{Fe}^{3+} \rightleftharpoons\left[\mathrm{Fe}_{3}(\mathrm{HCOO})_{6}\right]^{3+}$

$\left[\mathrm{Fe}_{3}(\mathrm{HCOO})_{6}\right]^{3+}+9 \mathrm{H}_{2} \mathrm{O} \rightleftharpoons 3 \mathrm{Fe}(\mathrm{OH})_{2} \mathrm{HCOO} \downarrow+3 \mathrm{HCOOH}+$ $+3 \mathrm{H}_{3} \mathrm{O}^{+}$

Fe content in this solid is $41 \mathrm{wt} \%$, close to the experimental value found.

Soluble iron corresponds to $\mathrm{Fe}(\mathrm{II})$, since only the test with ad-dipyridyl was positive (Feigl, 1958; Vogel, 1981). This means that formic acid partially reduced $\mathrm{Fe}(\mathrm{III})$ (BRATSCH, 1989):

$2 \mathrm{Fe}^{3+}+\mathrm{HCOO}-+\mathrm{OH}-\rightleftharpoons \mathrm{H}_{2} \mathrm{O}+\mathrm{CO}_{2}+2 \mathrm{Fe}^{2+}$

$\Delta E^{o}=+0,885 \mathrm{~V}$

\subsection{Solvent extraction of $\mathrm{Zn}$ (II), $\mathrm{Fe}$ (II), $\mathrm{Mn}$ (II) and Co(II)}

$\mathrm{Zn}(\mathrm{II})$ and $\mathrm{Fe}(\mathrm{II})$ were directly extracted from the original leachate $(\mathrm{pH} \sim 1.5)$ using 6 vol.\% D2EHPA with high yields (> 99.5 wt.\%) in one stage (Figures 6 and 7a). These elements were not detected in the raffinate (Table 4). The tests with dithizone $(\mathrm{Zn}(\mathrm{II}))$ and aa-dipyridyl (Fe(II)) were negative in the raffinate (Vogel, 1981; Feigl, 1958). The organic phase is pale olive-green (Fe(II)) whereas the raffinate was green $(\mathrm{Ni}(\mathrm{II}))$. These results agree with data of Balesini et al. (2011). Stripping of both ions from the loaded organic phase in a single stage was feasible using $1 \mathrm{~mol}$ $\mathrm{L}^{-1} \mathrm{H}_{2} \mathrm{SO}_{4}$ (Figure 8a).

$\mathrm{Mn}(\mathrm{II})$ was extracted from $\mathrm{pH} 2$ and was removed from the aqueous phase at $\mathrm{pH} 3.5$ (Figure 6) using 3 vol.\% D2E-
TABLE 3: Chemical analyses data of the insoluble matter after leaching with $10 \mathrm{~mol} \mathrm{~L}^{-1} \mathrm{HCOOH}\left(40^{\circ} \mathrm{C}, 3 \mathrm{~h}\right)$.

\begin{tabular}{c|c} 
Element & Amount (wt.\%) \\
\hline $\mathrm{Fe}$ & 99.83 \\
\hline $\mathrm{Ni}$ & 0.15 \\
\hline $\mathrm{La}$ & 0.02 \\
\hline
\end{tabular}

HPA in one stage. The raffinate contains less than $0.5 \mathrm{wt} . \%$ of the element (Table 4). Stripping of $\mathrm{Mn}$ (II) from the loaded organic phase in a single stage was feasible using $1 \mathrm{~mol}$ $\mathrm{L}^{-1} \mathrm{H}_{2} \mathrm{SO}_{4}$ (Ibiapina et al., 2018). Since the aqueous phase is colorless, the presence of $\mathrm{Mn}(\mathrm{II})$ was monitored using $\mathrm{NaBiO}_{3}+16 \mathrm{~mol} \mathrm{~L}^{-1} \mathrm{HNO}_{3}$ (Vogel, 1981; Feigl, 1958).

$\mathrm{Co}$ (II) began to be extracted at $\mathrm{pH}$ around 3.8 and was fully extracted at $\mathrm{pH} \sim 4.8$ (Figure 6 ). The organic phase was blue due to $\mathrm{Co}(\mathrm{II})$. The raffinate was green due to $\mathrm{Ni}(\mathrm{II})$. The minimum D2EHPA concentration to ensure Co(II) extraction (> $99.5 \mathrm{wt} . \%$ ) from the leachate at $\mathrm{pH} 4.8$ in one stage was 6 vol.\% (Figure 7b). Under these circumstances, the raffinate contains less than $0.5 \mathrm{wt}$.\% of the element (Table 4). Stripping of $\mathrm{Co}$ (II) from the loaded organic phase in a single stage was accomplished using $1 \mathrm{~mol} \mathrm{~L}^{-1} \mathrm{H}_{2} \mathrm{SO}_{4}$ (Figure 8b). About 10 wt.\% of leached $\mathrm{Ni}(\mathrm{II})$ passed to the organic phase. Its concentration in the raffinate (Table 4) is 10 wt.\% lower than in the leachate (Table 2).

The amount of $\mathrm{Ni}$ (II) is 8 times higher than $\mathrm{Co}$ (II) (Tables 1 and 2). The traditional solvent extraction method

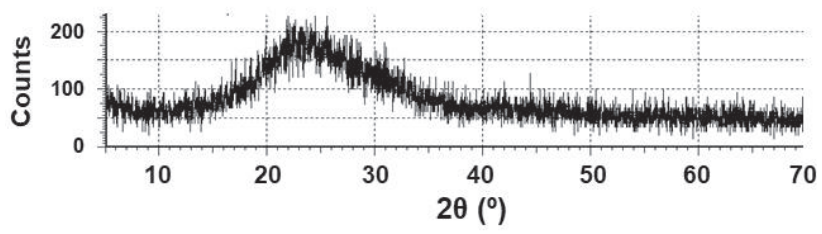

FIGURE 5: XDR patterns of the insoluble matter after leaching with $10 \mathrm{~mol} \mathrm{~L}^{-1} \mathrm{HCOOH}\left(40^{\circ} \mathrm{C}, 3 \mathrm{~h}\right)$.

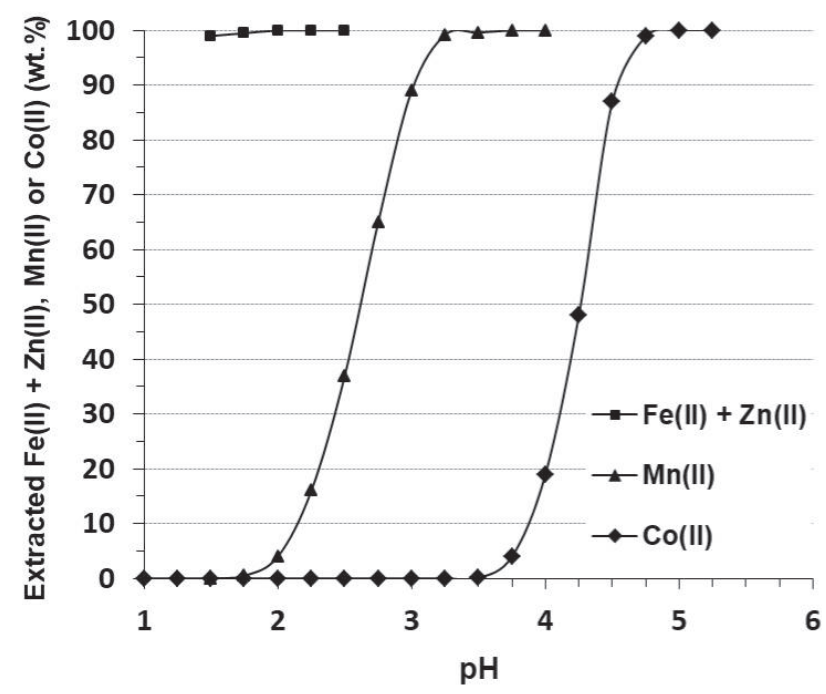

FIGURE 6: Extraction of $\mathrm{Zn}(\mathrm{II})+\mathrm{Fe}(\mathrm{II}), \mathrm{Mn}(\mathrm{II})$ and $\mathrm{Co}(\mathrm{II})$ with D2EHPA diluted in kerosene as a function of $\mathrm{pH}$ of the leachate. $\mathrm{A} / \mathrm{O}=$ 1 vol./vol., $25^{\circ} \mathrm{C}$, [D2EHPA] $=6$ vol\%. Leachant: $10 \mathrm{~mol} \mathrm{~L}-1 \mathrm{HCOOH}$. 


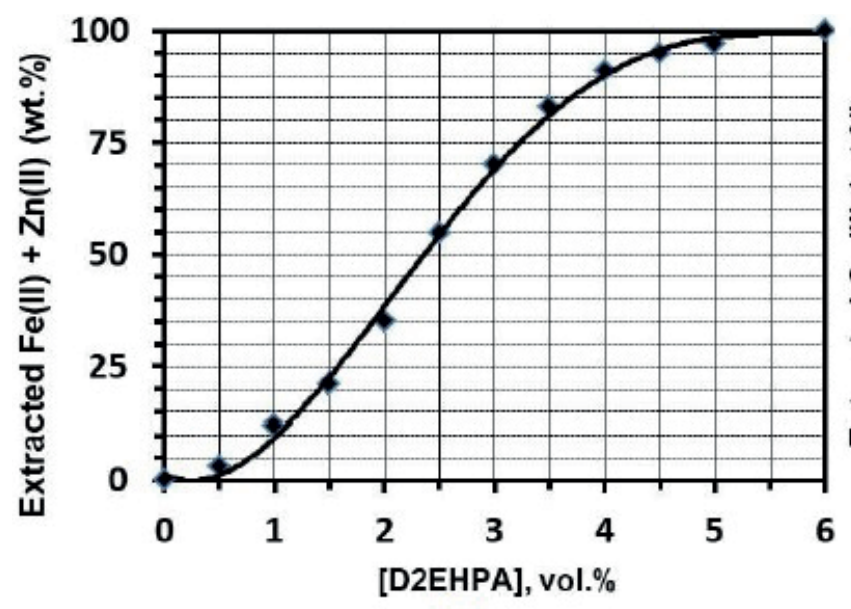

(a)

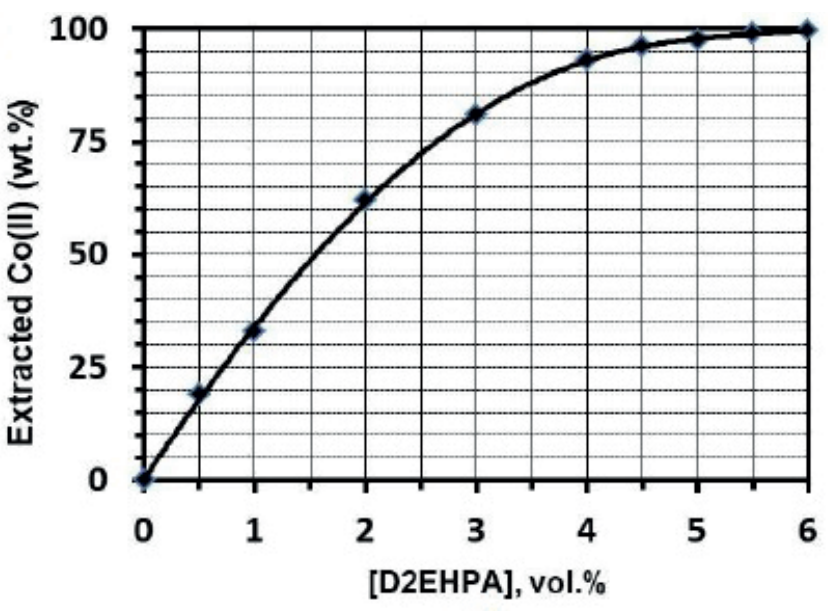

(b)

FIGURE 7: Influence of D2EHPA concentration on some elements extraction. A/O = 1 vol./vol., $25^{\circ} \mathrm{C}, \mathrm{pH}=1.5$ ( $\left.\mathrm{Zn}(\mathrm{II})+\mathrm{Fe}(\mathrm{II})\right)$ or 4.5 (Co(II)). Leachant: $10 \mathrm{~mol} \mathrm{~L}^{-1} \mathrm{HCOOH}$.

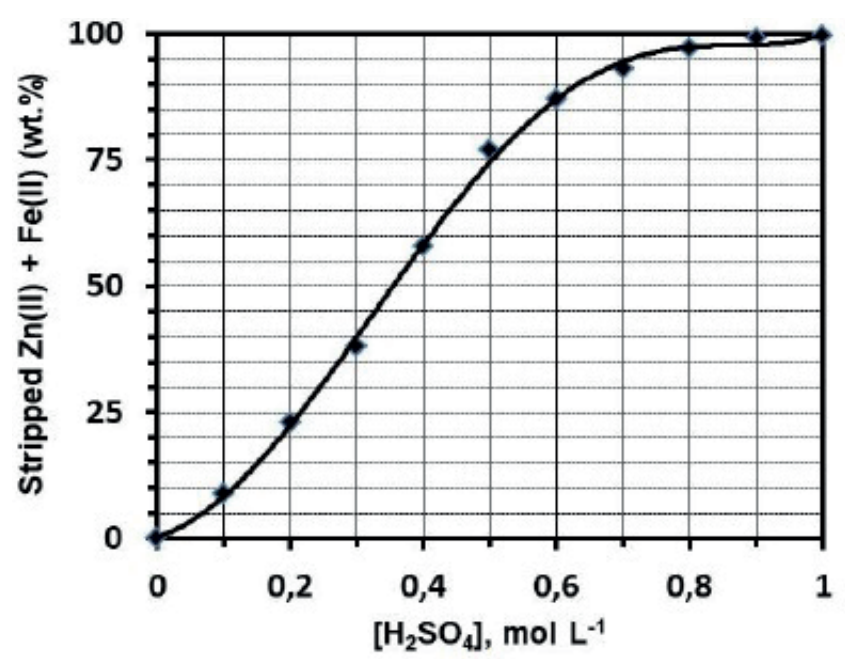

(a)

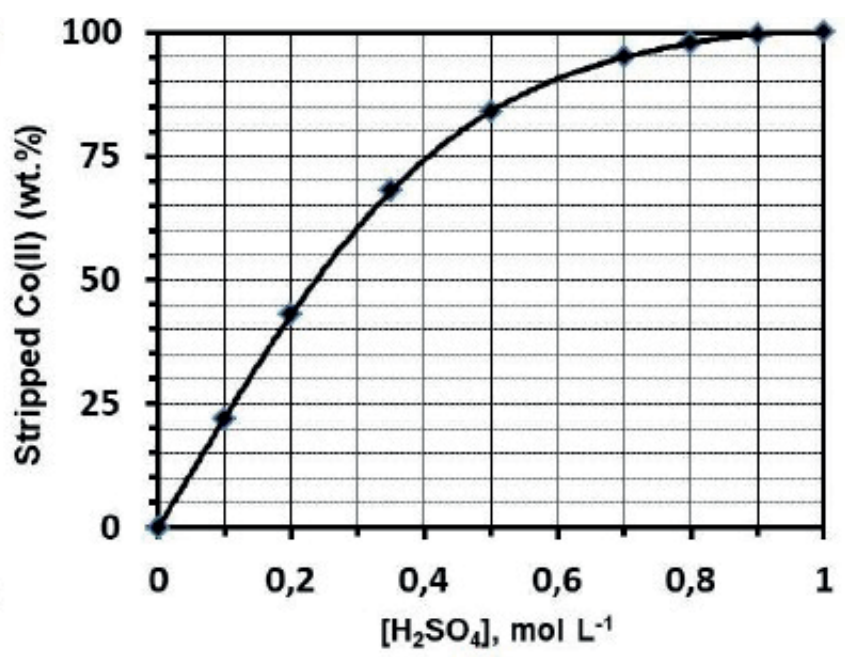

(b)

FIGURE 8: Influence of $\mathrm{H}_{2} \mathrm{SO}_{4}$ concentration on stripping of $\mathrm{Zn}(\mathrm{II})+\mathrm{Fe}(\mathrm{II})$ and $\mathrm{Co}(\mathrm{II})$ from loaded organic phase $\left(\mathrm{A} / \mathrm{O}=1 \mathrm{vol} . / \mathrm{vol}\right.$., $\left.25^{\circ} \mathrm{C}\right)$.

for separating $\mathrm{Ni}$ and $\mathrm{Co}$ from a leach liquor rich in nickel is prone to cause nickel loss (van der Voorde et al., 2019; Yang et al., 2020). Extraction of $\mathrm{Co}$ (II) is more selective at $\mathrm{pH}$ below 4, but requires more stages, thus increasing consumption of the extractant and diluent (van der Voorde et al., 2019). Processing of Ni-rich spent materials is feasible by changing the extractant, for example, Cyanex 272 (bis(2,4,4-trimethylpentyl)phosphinic acid) (Janiszewska et al., 2019). It is very selective for cobalt over nickel in sulfate and chloride media (Ayanda et al., 2013).

$\mathrm{pH}$ was not practically changed after $\mathrm{Mn}$ (II) and $\mathrm{Co}(\mathrm{II})$ extractions. Formic acid is a weak acid and its ionization process in aqueous phase can be expressed as follows (Lurie, 1978):

$$
\mathrm{HCOOH}+\mathrm{H}_{2} \mathrm{O} \rightleftharpoons \mathrm{H}_{3} \mathrm{O}++\mathrm{HCOO}^{-} \mathrm{pKa}=3.77
$$

Thus, the leachate was buffered during solvent extraction of $\mathrm{Mn}$ (II) and $\mathrm{Co}$ (II) by a formic acid/formate buffer $(2.77<\mathrm{pH}<4.77)$.
The extraction order $\mathrm{Zn}(\mathrm{II})+\mathrm{Fe}(\mathrm{II})-\mathrm{Mn}(\mathrm{II})-\mathrm{Co}(\mathrm{II})$ under increasing $\mathrm{pH}$ found in this work is the same reported in the literature in sulfate (Ritcey and Ashbrook, 1984) and fluoride media (Silva et al., 2018). This result is in line with the weak ligand character of the formate anion (Lurie, 1978).

Stripping produces a dilute aqueous acidic solution $\left(\mathrm{H}_{2} \mathrm{SO}_{4}\right)$ of a metal ion sulfate $\left(\mathrm{ZnSO}_{4}, \mathrm{FeSO}_{4}, \mathrm{MnSO}_{4}, \mathrm{CoSO}_{4}\right.$ and $\mathrm{NiSO}_{4}$ ) because the metal ion concentrations in the leachate are relatively low (Table 2 ) and the $A / O$ phase ratio was fixed at $1 \mathrm{v} / \mathrm{v}$. The concentrations in these acidic solutions are very close to the original leachate (Table 2) as both solvent extraction and stripping were prformed with high yields (> 99.5 wt.\%). Zn(II) can be easily separated from $\mathrm{Fe}(\mathrm{II})$ by adding $\mathrm{NaOH}_{\mathrm{aq}} \cdot(\mathrm{pH} \sim 11)$ : $\mathrm{Fe}(\mathrm{OH})_{2}$ precipitates in the presence of soluble $\left[\mathrm{Zn}(\mathrm{OH})_{4}\right]^{2-} \mathrm{Zn}(\mathrm{II})$ can be recovered as $\mathrm{Zn}(\mathrm{OH})_{2}$ after neutralizing the alkaline solution with $\mathrm{H}_{2} \mathrm{SO}_{4 \mathrm{aq}}$. (Fernandes et al., 2012). Mn(II) can be precipitated as $\mathrm{MnO}_{2}$ (or $\mathrm{MnO}(\mathrm{OH})_{2}$ ) after adding $\mathrm{NaOH}_{\text {aq }}$. 
TABLE 4: Element concentrations in the raffinates after solvent extraction and in the aqueous acidic solutions after stripping the loaded organic phase with $1 \mathrm{~mol} \mathrm{~L}^{-1} \mathrm{H}_{2} \mathrm{SO}_{4}$

\begin{tabular}{|c|c|c|c|}
\hline \multirow[b]{2}{*}{ Element } & \multirow[b]{2}{*}{ Solvent extraction procedure* } & \multicolumn{2}{|c|}{ Concentration (g L-1) } \\
\hline & & Raffinate & $\begin{array}{l}\text { Acidic } \\
\text { solution }\end{array}$ \\
\hline $\mathrm{Fe}$ & D2EHPA $6 \%$ vol., pH 1.5 & n.d & $4.9 \times 10^{-1}$ \\
\hline $\mathrm{Zn}$ & D2EHPA $6 \%$ vol., $\mathrm{pH} \sim 1.5$ & n.d & $7.2 \times 10^{-1}$ \\
\hline $\mathrm{Mn}$ & D2EHPA 3\% vol., pH 3 & $6.0 \times 10^{-2}$ & 1.3 \\
\hline Co & D2EHPA $6 \%$ vol., pH 4.8 & $1.5 \times 10^{-2}$ & 3.0 \\
\hline $\mathrm{Ni}$ & D2EHPA $6 \%$ vol., $\mathrm{pH} \sim 4.8$ & $2.5 \times 10^{1}$ & 2.6 \\
\hline
\end{tabular}

(pH 11) $+\mathrm{H}_{2} \mathrm{O}_{2}$ (Ibiapina et al., 2018). $\mathrm{Co}(\mathrm{II})$ and $\mathrm{Ni}(\mathrm{II})$ can also be recovered as hydroxides $\left(\mathrm{Co}(\mathrm{OH})_{2}\right.$ and $\left.\mathrm{Ni}(\mathrm{OH})_{2}\right)$ upon addition of $\mathrm{NaOH}_{\mathrm{aq}}$. ( $\left.\mathrm{pH} \sim 10\right)$ (Silva et al., 2018). In all cases an aqueous sodium sulfate is the final product, which can be recovered by slow evaporation of the final solution (Paulino et al., 2018).

\subsection{Precipitation of REEs}

According to data in Table 5 , only small amounts of nickel ( 0.1 wt.\%) were found. $\mathrm{Ni}(\mathrm{II})$ oxalate precipitates at higher $\mathrm{pH}$, usually above 3 (Lurie, 1978; Vogel, 1981; Feigl, 1958).

Based on data in Table 2, $23.4 \mathrm{~g}$ of REE oxalates $\left(\mathrm{REE}_{2}(-\right.$ $\left.\mathrm{C}_{2} \mathrm{O}_{4}\right)_{3}$ ) can be recovered from $1 \mathrm{~L}$ of lecahate. The experimental value found was $23.3 \mathrm{~g} \mathrm{~L}^{-1}$. This means that over 99.5 wt.\% of lanthanides and yttrium were recovered in this solid. Threfore, precipitation of REE oxalates was a very selective and effective technique under our experimental

TABLE 5: Chemical analyses data of the oxalates $\left(\operatorname{REE}_{2}\left(\mathrm{C}_{2} \mathrm{O}_{4}\right)_{3}\right.$ and $\mathrm{NiC}_{2} \mathrm{O}_{4}$ ) recovered after processing the leachates (Figure 1) $\left(10 \mathrm{~mol} \mathrm{~L}^{-1} \mathrm{HCOOH}, 40^{\circ} \mathrm{C}, 3 \mathrm{~h}\right)$

\begin{tabular}{c|ccc}
\hline Element & \multicolumn{2}{c}{ Amount (wt.\%) } \\
\hline $\mathrm{Ni}$ & $\mathrm{REE}_{2}\left(\mathbf{C}_{2} \mathbf{O}_{\mathbf{4}}\right)_{3}$ & $\mathbf{N i C}_{2} \mathbf{O}_{4}$ \\
\hline $\mathrm{La}$ & 0.1 & 98.0 \\
\hline $\mathrm{Ce}$ & 73.4 & n.d. \\
\hline $\mathrm{Pr}-\mathrm{Sm}$ & 19.2 & n.d. \\
\hline $\mathrm{Y}$ & 5.6 & n.d. \\
\hline $\mathrm{Ca}$ & 1.7 & n.d \\
\hline n.d. - not detected & n.d. & 2.0 \\
\hline
\end{tabular}

conditions, as the oxalates were recovered with high yield and purity.

An advantage of oxalate salts is their easy conversion to other REE compounds as they are easily thermally decomposed (Yang et al., 2014) and oxidized (Josso et al., 2018).

\subsection{Precipitation of $\mathrm{Ni}(\mathrm{II})$}

XRF analysis (Table 5) of the green solid found calcium (1.9 wt.\%). Based on data in Table $2,69.2 \mathrm{~g}$ of nickel oxalate can be recovered from $1 \mathrm{~L}$ of lecahate. $63.9 \mathrm{~g}$ were recovered, $62.6 \mathrm{~g}$ of which correspond to $\mathrm{NiC}_{2} \mathrm{O}_{4}$ ( $90.5 \mathrm{wt}$.\% of the theoretical value). This difference is due to partial solvent extraction of $\mathrm{Ni}$ (II) by D2EHPA at $\mathrm{pH} 4.8$ (Section 3.4). $1.3 \mathrm{~g}$ of $\mathrm{CaC}_{2} \mathrm{O}_{4}$ contains $\sim 80 \mathrm{wt}$ \% of leached calcium.

\subsection{Crystallization of sodium formate}

The solid precipitated at $\mathrm{pH} \sim 8\left(\sim 0.1 \mathrm{~g} \mathrm{~L}^{-1}\right.$ processed leachate) contains aluminum and the remaining calcium. According to XRF data (Table 6), the solid also contains minute amounts of nickel ( $0.1 \mathrm{wt} . \%)$. This step is essential to recover sodium formate with high purity.

The diffractogram (Figure 9) of the white crystalline solid obtained after evaporation of the final aqueous solution corresponds to anhydrous $\mathrm{HCOONa}$. The peaks agree with the standard pattern of monoclinic HCOONa (ICDD PDF Card No. 00-014-0812).

XRF data (Table 6) did not show significant amounts of other metals. However, addition of sodium oxalate to precipitate $\mathrm{NiC}_{2} \mathrm{O}_{4}$ must be carefully controlled in order to avoid an undesirable excess of oxalate ions, otherwise sodium formate would be contaminated with sodium oxalate.

Sodium formate is a very versatile reactant in laboratory syntheses, in pharmaceutical, textile, paper and leather industries for buffering and regulating of $\mathrm{pH}$ (Hietala et al., 2016). This salt is used to produce formic acid. It is a raw material for manufacturing sodium dithionite. Oxalic acid production employs sodium formate as an intermediate. Sodium formate is used in chrome tanning and as a mordant in the dyeing and printing of fabrics by the textile industry. The reducing power of sodium formate is utilized in electroplating baths and photographic fixing baths. (Reutmann and Kieczka, 2012). It is also a food additive (E237) and a deicing agent (Kulyakthin and Paste, 2021).

\subsection{Mass balance for formate ion}

Based on the composition of the leachant $\left(10 \mathrm{~mol} \mathrm{~L}^{-1}\right.$ $\mathrm{HCOOH}$ ), and the mass of the recovered salt, sodium for-

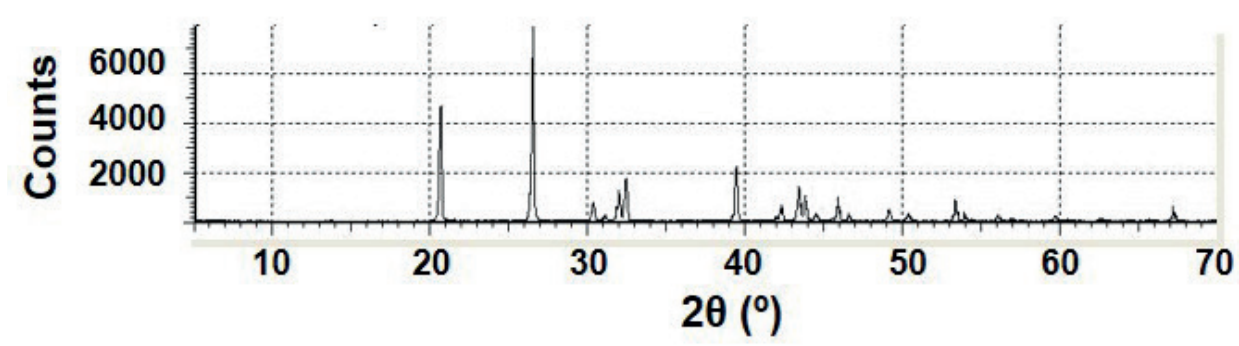

FIGURE 9: XRD patterns of the solid recovered after evaporation of the final solution. The peaks represent HCOONa. 
TABLE 6: Chemical analyses data of the solid precipitated at $\mathrm{pH}$ $\sim 8$ and of sodium formate after evaporation of the final aqueous solution

\begin{tabular}{c|ccc}
\hline \multirow{2}{*}{ Element } & \multicolumn{2}{c}{ Amount (wt.\%) } \\
\hline $\mathrm{Ni}$ & Solid & HCOONa \\
\hline $\mathrm{Ca}$ & 0.1 & n.d. \\
\hline $\mathrm{Al}$ & 25.0 & n.d. \\
\hline $\mathrm{Na}$ & 74.6 & n.d. \\
\hline $\mathrm{REEs}$ & 0.3 & 100 \\
\hline n.d. - not detected & n.d. & n.d. \\
\hline
\end{tabular}

TABLE 7: Mass balance for formate ion (base: $1 \mathrm{~L}$ leachate).

\begin{tabular}{c|cccc}
$\begin{array}{c}\text { Product/ } \\
\text { Leachant }\end{array}$ & $\begin{array}{c}\text { Mass } \\
\mathbf{( g )}\end{array}$ & $\begin{array}{c}\text { Mass of } \\
\text { HCOO-(g) }\end{array}$ & $\begin{array}{c}\text { Relative } \\
\text { amount (wt.\%) }\end{array}$ \\
\hline $\begin{array}{c}10 \mathrm{~mol} \mathrm{~L}^{-1} \\
\mathrm{HCOOH}\end{array}$ & - & 450.0 & 100 \\
\hline $\mathrm{HCOONa}$ & 603.7 & 399.5 & 89 \\
\hdashline Losses & - & 50.5 & 11 \\
\hline
\end{tabular}

mate contains around $90 \mathrm{wt} \%$ of the total formate (Table 7). Two potential sources of loss of formate ions were identified: (i) during leaching, when it acts a reductant; (ii) as iron(III) basic formate. The huge amount of the salt recovered is due to the concentration of formic acid in the leachant $\left(10 \mathrm{~mol} \mathrm{~L}^{-1}\right)$.

On an average basis, the price of sodium formate (99 wt.\%) is about 1.5 times the cost of formic acid (95-98 wt.\%) (Hietala et al., 2016; Reutmann \& Kieczka, 2012).

\section{CONCLUSIONS}

Under the best experimental conditions (10 $\mathrm{mol} \mathrm{L}^{-1}$ $\mathrm{HCOOH}, 40^{\circ} \mathrm{C}, 3 \mathrm{~h}$ ), nickel, manganese, cobalt, zinc and REEs were leached from the electroactive components of spent $\mathrm{Ni}-\mathrm{MH}$ batteries with very high yields as found for common inorganic acids. The insoluble matter contains $~ 80 \mathrm{wt} . \%$ of the iron present in the original mass as Fe(III) basic formate. The remaining iron was in the leachate as $\mathrm{Fe}(\mathrm{II})$.

Recovery of leached elements by solvent extraction using D2EHPA and precipitation of REE and Ni(II) oxalates at suitable $\mathrm{pH}$ was possible. The original leachate allowed direct extraction of $\mathrm{Zn}(\mathrm{II})+\mathrm{Fe}(\mathrm{II})$ and REE oxalates were direcly recovered from the raffinate. However, the recovery of $\mathrm{Co}$ (II) in the presence of large amounts of $\mathrm{Ni}(\mathrm{II})$ by solvent extraction requires further studies. About $90 \mathrm{wt} \%$ of formate present in the leachant was recovered as sodium formate after evaporation of the final solution.

Formic acid has proven a promising leachant for spent $\mathrm{Ni}-\mathrm{MH}$ batteries: i) it played the dual role of leachant and reductant for nickel, thus avoiding addition of a reductant like hydrogen peroxide; ii) the elements were leached with very high yields (except iron); iii) its leahates were easily processed; iv) a high-value added byproduct was recovered (sodium formate), thus reducing generation of final wastes.

\section{ACKNOWLED GEMENTS}

The authors would like to thank Council of Technological and Scientific Development (CNPq) for financial support. P. R. Gismonti acknowledges PIBIC/CNPq-UFRJ for a fellowship.

\section{REFERENCES}

Almeida, J. R., Moura, M. N., Barrada, R. V., Barbieri, E. M. S., Carneiro, M. T. W. D., Ferreira, S. A. D., Lelis, M. F. F., Freitas, M. B. J. G. \& Brandão, G. P., 2019. Composition analysis of the cathode active material of spent Li-ion batteries leached in citric acid solution: A study to monitor and assist recycling processes. Sci. Total Environ., 685, 589-595. https://doi.org/10.1016/j.scitotenv.2019.05.243

Alonso, A.R., Pérez, E.A., Lapidus, G.T. \& Luna-Sánchez, R.M., 2017. Hydrometallurgical process for rare earth elements recovery from spent Ni-MH batteries. Can. Metall. Q., 54, 310-317. https://doi.or g/10.1179/1879139515Y.0000000013

Ayanda, O. S., Adekola, F. A., Baba, A. A., Ximba, B. J. \& Fatoki, O. S., 2013. Application of Cyanex ${ }^{\circledR}$ extractant in Cobalt/Nickel separation process by solvent extraction. Int. J. Phys. Sci., 8, 89-97. https://doi.org/10.5897/ijps12.135

Balesini, A. A., Razavizadeh, H. \& Zakeri, A., 2011. Solvent Extraction of Zinc from Acidic Solution Obtained from Cold Purification Filter Cake of Angouran Mine Concentrate Using D2EHPA. Iran. J. Chem. Chem. Eng., 8, 43-47. http://www.ijche.com/article_10282_813d0dccf4d682c66c2d73e654476a86.pdf

Barik, S. P., Prabaharan, G. \& Kumar, L., 2017. Leaching and separation of $\mathrm{Co}$ and $\mathrm{Mn}$ from electrode materials of spent lithium-ion batteries using hydrochloric acid: Laboratory and pilot scale study. J. Cleaner Prod., 147, 37-43. https://doi.org/10.1016/j.jclepro.2017.01.095

Bratsch, S. G., 1989. Standard Electrode Potentials and Temperature Coefficients in Water at 298.5 K. J. Phys. Chem. Ref. Data, 18, n. 01. https://doi.org/10.1063/1.555839

Chen, X., Guo, C., Ma, H., Li, J., Zhou, T., Cao, L. \& Kang, D., 2018. Organic reductants based leaching: A sustainable process for the recovery of valuable metals from spent lithium ion batteries. Waste Manage., 75, 459-468. https://doi.org/10.1016/j.wasman.2018.01.021

Chiu, K. L., Shen, Y. H., Chen, Y. H. \& Shih, K. Y., 2019. Recovery of Valuable Metals from Spent Lithium Ion Batteries (LIBs) Using Physical Pretreatment and a Hydrometallurgy Process. Adv. Mater., 8, 1220. https://doi.org/10.11648/j.am.20190801.12

Colmenares, A. Z., Salaverría, J. D. \& Delvasto, P., 2018. Characterization of the chemical compounds obtained after using acetic acid as leaching agent in the hydrometallurgical treatment of spent Ni-MH batteries. Revista Producción + Limpia, 13, 19-29. http:// dx.doi.org/10.22507/pml.v13n1a2

Dhiman, S. \& Gupta, B., 2019. Partition studies on cobalt and recycling of valuable metals from waste Li-ion batteries via solvent extraction and chemical precipitation. J. Cleaner Prod., 225, 820-832. https://doi.org/10.1016/j.jclepro.2019.04.004

Feigl, F., 1958. Spot Tests in Inorganic Analysis. Amsterdam: Elsevier.

Fernandes, A., Afonso, J. C. \& Dutra, A. J. B., 2013. Separation of nickel(II), cobalt(II) and lanthanides from spent $\mathrm{Ni}-\mathrm{MH}$ batteries by hydrochloric acid leaching, solvent extraction and precipitation. Hydrometallurgy, 133, 37-43. http://dx.doi.org/10.1016/j.hydromet.2012.11.017

Fernandes, A., Afonso, J. C. \& Dutra, A. J. B., 2012. Hydrometallurgical route to recover nickel, cobalt and cadmium from spent $\mathrm{Ni}-\mathrm{Cd}$ batteries. J. Power Sources 220, 286-291. https://doi.org/10.1016/j. jpowsour.2012.08.011

Fila, D., Hubicki, Z. \& Kołodyńska, D., 2019. Recovery of metals from waste nickel-metal hydride batteries using multifunctional Diphonix resin. Adsorption, 25, 367-382. https://doi.org/10.1007/ s10450-019-00013-9

Fu, Y., He, Y., Chen, H., Ye, C., Lu, Q., Li, Xie, W. \& Wang, J., 2019. Effective leaching and extraction of valuable metals from electrode material of spent lithium-ion batteries using mixed organic acids leachant. J. Ind. Eng. Chem., 79, 154-162. https://doi.org/10.1016/j. jiec.2019.06.023 
Gaines, L., 2018. Lithium-ion battery recycling processes: Research towards a sustainable course. Sust. Mater. Technol., 17, e00068. https://doi.org/10.1016/j.susmat.2018.e00068

Gao, W., Liu, C., Cao, H., Zheng, X., Lin, X., Wang, H., Zhang, Y. \& Sun, Z., 2018. Comprehensive evaluation on effective leaching of critical metals from spent lithium-ion batteries. Waste Manage., 75, 477-485. https://doi.org/10.1016/j.wasman.2018.02.023

Hayrapetyan, S. S.; Mangasaryan, L. G. Tovmasyan, M. R. \& Khachatryan, H. G., 2006. Precipitation of aluminum hydroxide from sodium aluminate, by treatment with formalin, and preparation of aluminum oxide. Acta Chromatographica 16, 192-203. http:// yadda.icm.edu.pl/yadda/element/bwmeta1.element.baztech-article-BAT3-0037-0020

Hietala, J., Vuori, A., Johnsson, P., Pollari, I., Reutemann, W. \& Kieczka, H., 2016. Formic acid. In Ullmann's Encyclopaedia of Industrial Chemistry, Wiley-VCH Verlag GmbH \& Co. KGaA, https://doi. org/10.1002/14356007.a12_013.pub3

Ibiapina, V. F., Florentino, U. S., Afonso, J. C., Gante, V., Vianna, C. A. \& Mantovano, J. L., 2018. Processing of spent zinc- $\mathrm{MnO}_{2}$ dry cells in various acidic media. Quim. Nova 41, 176-183. https://doi. org/10.21577/0100-4042.20170162

Janiszewska, M., Markiewicz, A. \& Regel-Ros, M., 2019. Hydrometallurgical separation of $\mathrm{Co}(\mathrm{II})$ from $\mathrm{Ni}(\mathrm{II})$ from model and real waste solutions. J. Cleaner Prod., 228, 746-754. https://doi. org/10.1016/j.jclepro.2019.04.285

Josso, P., Roberts, S., Teagle, D. A. H., Pourret, O., Herrington, R. \& Albarran, C. P. L., 2018. Extraction and separation of rare earth elements from hydrothermal metalliferous sediments. Miner. Eng., 118, 106121. https://doi.org/10.1016/j.mineng.2017.12.014

Korkmaz, K., Alemrajabi, M., Rasmuson, A.. C. \& Forsberg, K. M., 2018. Sustainable hydrometallurgical recovery of valuable elements from spent nickel-metal hydride HEV batteries. Metals, 8, 1062 https://doi.org/10.3390/met8121062

Kulyakthin, S. \& Pastye, A. K., 2021. Can calorimetry be used to measure the melting rate of deicers? Cold Reg. Sci. Technol., 181, article 103170. https://doi.org/10.1016/j.coldregions.2020.103170

Liu, X., Li, S., Liu, Y. \& Cao, Y., 2015. Formic acid: A versatile renewable reagent for green and sustainable chemical synthesis. Chinese J. Catal., 36, 1461-1475. https://doi.org/10.1016/S18722067(15)60861-0

Lucas, J., Lucas, P., Le Mercier, T., Rollat, A. \& Davenport, W., 2015. Rare earths in rechargeable batteries. Rare Earths, 167-180 (Chapter 10). https://doi.org/10.1016/B978-0-444-62735-3.00010-3

Lurie, J., 1978. Handbook of Analytical Chemistry, 3rd ed. Mir, Moscow.

Meshram, P., Pandey, B. D. \& Mankhand, T. R., 2016. Process optimization and kinetics for leaching of rare earth metals from the spent $\mathrm{Ni}-$ metal hydride batteries. Waste Manage., 51, 196-203. https:// doi.org/10.1016/j.wasman.2015.12.018

Meshram, P., Somani, H., Pandey, B. D., Mankhand, T. R., Deveci, H. \& Abhilash, 2017. Two stage leaching process for selective metal extraction from spent nickel metal hydride batteries. J. Cleaner Prod. 157, 322-332. https://doi.org/10.1016/j.jclepro.2017.04.144

Meshram, P., Pandey, B. D. \& Abhilash, 2019. Perspective of availability and sustainable recycling prospects of metals in rechargeable batteries - A resource overview. Resour. Policy, 60, 9-22. https://doi. org/10.1016/j.resourpol.2018.11.015

Meshram, P., Mishra, \& Sahu, R., 2020. Environmental impact of spent lithium ion batteries and green recycling perspectives by organic acids: a review. Chemosphere, 242, 125291. https://doi. org/10.1016/j.chemosphere.2019.125291

Musariri, B., Akdogan, G., Dorfling, C. \& Bradshaw, S., 2019. Evaluating organic acids as alternative leaching reagents for metal recovery from lithium ion batteries. Miner. Eng., 137, 108-117. https://doi. org/10.1016/j.mineng.2019.03.027
Oliveira, U. C. M., Rodrigues, G. D., Mageste, A. B. \& Lemos, L. R., 2017. Green selective recovery of lanthanum from $\mathrm{Ni}-\mathrm{MH}$ battery leachate using aqueous two-phase systems. Chem. Eng. J., 322, 346-352. https://doi.org/10.1016/j.cej.2017.04.044

Paulino, J. F., Neumann, R., Afonso, J. C., 2018. Production of sodium and aluminum chemicals and recovery of rare earth elements after leaching cryolite from Pitinga mine (Amazonas - Brazil) with sulfuric acid. Hydrometallurgy, 180, 254-261. https://doi.org/10.1016/j. hydromet.2018.08.004

Reutmann, W., Kieczka, H., 2012. Formic Acid. Ullmann's Encyclopedia of Industrial Chemistry. Weinhein: Wiley-VCH Verlag, vol. 16, p. 1333. https://onlinelibrary.wiley.com/doi/epdf/10.1002/14356007. a12_013.pub2

Ritcey, G. M. \& Ashbrook, A. W., 1984. Principles and Applications to Process Metallurgy (Part I). New York, Elsevier Science Publishers.

Shih, Y. J., Chien, S. K., Jhang, S. R. \& Lin, Y. C., 2019. Chemical leaching precipitation and solvent extraction for sequential separation of valuable metals in cathode material of spent lithium ion batteries. J. Taiwan Inst. Chem. E., 100, 151-159. https://doi.org/10.1016/j. jtice.2019.04.017

Santos, V. E. O., Celante, V. G., Lelisa, M. F. F. \& Freitas, M. B. J. G., 2014 Método hidrometalúrgico para reciclagem de metais terras raras, cobalto, níquel, ferro e manganês de eletrodos negativos de baterias exauridas de Ni-MH de telefone celular. Quim. Nova, 37, 22-26. http://dx.doi.org/10.1590/S0100-40422014000100005

Silva, R. G., Afonso, J. C. \& Mahler, C. F., 2018. Acidic leaching of Li-ion batteries. Quim. Nova, 41, 581-586. http://dx.doi. org/10.21577/0100-4042.20170207

Turek, A. S., 2018. Hydrometallurgical recovery of metals: Ce, La, Co, Fe $\mathrm{Mn}, \mathrm{Ni}$ and $\mathrm{Zn}$ from the stream of used Ni-MH cells. Waste Manage., 77, 213-219. https://doi.org/10.1016/j.wasman.2018.03.046

Valadares, A., Valadares, C. F., Lemos, L. R., Mageste, A. B. \& Rodrigues, G. D., 2018. Separation of cobalt and nickel in leach solutions of spent nickel-metal hydride batteries using aqueous two-phase systems (ATPS). Hydrometallurgy, 181, 180-188. https://doi. org/10.1016/j.hydromet.2018.09.006

van der Voorde, I., Pinoy, L., Courtijn, E., Verpoort, F., 2006. Equilibrium Studies of Nickel(II), Copper(II), and Cobalt(II) Extraction with Aloxime 800, D2EHPA, and Cyanex Reagents. Solvent Extr. Ion Exc., 24, 893-914. https://doi.org/10.1080/07366290600952717

Virolainen, S., Ibana, D. \& Paatero, E., 2011. Recovery of indium from indium-tin-oxide by solvent extraction. Hydrometallurgy, 107, 5661. https://doi.org/10.1016/j.hydromet.2011.01.005

Vogel, A. I., 1981. Química Analítica Qualitativa, 5a ed. São Paulo: Mestre Jou.

Wang, S., Wang, C., Lai, F., Yan, F. \& Zhang, Z., 2020. Reduction-ammoniacal leaching to recycle lithium, cobalt, and nickel from spent lithium-ion batteries with a hydrothermal method: Effect of reductants and ammonium salts. Waste Manage., 102, 122-130. https://doi. org/10.1016/j.wasman.2019.10.017

Xie, F., Zhang, T.A., Dreisinger, D., Doyle, F., 2014. A critical review on solvent extraction of rare earths from aqueous solutions. Miner. Eng., 56, 10-28. https://doi.org/10.1016/j.mineng.2013.10.021

Yang, X., Zhang, J. \& Fang, X., 2014. Rare earth element recycling from waste nickel metal hydride batteries. J. Hazard. Mat., 279, 384388. https://doi.org/10.1016/j.jhazmat.2014.07.027

Yang, L., Yang, L., Xu, G., Feng, Q., Li, Y., Zhao, E., Ma, J., Fan, S. \& Li, X. 2019. Separation and recovery of carbon powder in anodes from spent lithium-ion batteries to synthesize graphene. Sci. Rep., 9, 9823. https://doi.org/10.1038/s41598-019-46393-4 